\title{
Pembinaan Pendidikan Karakter Cerdas melalui Format Kelompok (PKC-KO) untuk Membantu Mengatasi Kesulitan Belajar di SMK Tecma Ciambar
}

\author{
Evi Fitriyanti*, Solihatun, Sisca Folastri \\ Bimbingan dan Konseling, Fakultas Ilmu Pendidikan dan Pengetahuan Sosial, \\ Universitas Indraprasta PGRI \\ *ibukevifitriyanti.21@gmail.com
}

\begin{abstract}
Abstrak
PKC-KO merupakan kegiatan kelompok yang mengahayati dan mengamalkan nilainilai karakter cerdas dalam wujud perilaku dan kehidupan pada umumnya. Tujuan pengabdian kepada masyarakat ini adalah membantu Guru Bimbingan Konseling (BK) untuk dapat meguasaiteknik pelayanan konseling melalui PKC-KO dan juga memberikan pendampingan dengan memberikan pembinaan berupa penguatan dan pengoptimalan karakter cerdas melalui karakter akademik yang positif di dalam diri Siswa agar mampu secara mandiri melakukan problem solving atas permasalahan kesulitan belajar yang dirasakan. Adapun kegiatan pengabdian masyarakat ini dilakukan melalui metode klasikal yang dikombinasikan dengan ceramah dan Tanya jawab. Sasaran dari kegiatan Pengabdian kepada Masyarakat ( ABDIMAS) ini adalah Guru BK dan Siswa di Sekolah Menengah Kejuruan (SMK) Tecma Ciambar sebagai mitra kegiatan. Hasil kegiatan menunjukan adanya perubahan baik dalam wawasan, pengtahuan, keterampilan, nilai, dan sikap Guru BK di dalam menguasai teknik pelayanan konseling melalui PKC-KO, dan teratasinya permasalahan kesulitan belajar yang di alami oleh siswa di SMK Tecma Ciambar sehingga kegiatan ini memiliki kebermanfaatan yang merupakan hal penting dalam kegiatan pengabdian.
\end{abstract}

Kata kunci: format kelompok, karakter cerdas, kesulitan belajar.

\section{PENDAHULUAN}

Kondisi pandemi Corona virus diseases 2019 (COVID-19) yang terjadi membuat proses kegiatan pembelajaransaat ini ditempuh oleh peserta didik adalah melalui kegiatan pembelajaran jarak jauh melalui sistem online. Sudah selama hampir dua tahun kegiatan pembelajaranjarak jauh dengan sistem online ini berlangsung dan di dalam pelaksanaannya terdapat kendala yang dihadapi oleh peserta didik. Kendala yang banyak di temukan salah satunya adalah kesulitan belajar. Prayitno (dalam Zulfahmi \& Handayani, 2020) menyatakan kesulitan belajar dapat diartikan sebagai suatu kondisi dalam proses belajar mengajar yang ditandai dengan adanya hambatan-hambatan tertentu untuk mencapai hasil belajar yang optimal.

Lebih lanjut menurut Ilyas, Folastri \& Solihatun (2017), kesulitan belajar merupakan suatu kondisi atau keadaan dimana terdapat suatu jarak antara prestasi akademik yang diharapkan dengan yang diperoleh yang ditandai oleh adanya hambatan tertentu. Hambatan-hambatan tersebut mungkindirasakan atau mungkin tidak dirasakan oleh siswa yang bersangkutan. Jenis hambatan ini dapat bersifat psikologis, sosiologis dan fisiologis dalam keseluruhan proses belajar mengajar. Kesulitan belajar dapat dialami oleh semua pembelajar baik formal maupun nonformal, dari jenjang pendidikan terendah sampai tertinggi dimungkinkan 
mengalamikesulitan belajar (Winarti, 2021). Sesuai dengan penelitian yang pernah dilakukan oleh Solihatun (2019) bahwa gambaran kesulitan belajar setiap indikator berdasarkan dari hasil penyebaran AUM PTSDL terungkap bahwa subvariabel sarana dan prasarana $69,35 \%$ merupakan permasalahan yang perlu ditingkatkan agar menjadi lebih baik agar hambatan siswadalam belajar bisa terurai.

Lebih lanjut berdasarkan hasil wawancara yang dilakukan oleh tim ABDIMAS kepada guru BK di SMK Tecma Ciambar hasil wawancara tersebut terungkap bahwa siswa disana mengalami konsentrasi yang menurun, dimungkinkan karena pada masa pandemic ini mengharuskan siswa untuk beradaptasi dengan kegiatan pembelajaran yang berbeda, selain itu sarana dan prasarana siswa itu sendiri yang kurang mendukung sehingga terjadilah permasalahan kesulitan belajar, sehingga menurunnya motivasi belajar siswa dan prestasi belajar nya pun akan menurun.

Berdasarkan dari beberapa permasalahan diatas, maka salah satu upaya yang dapat dilakukan adalah melalui pemberian pelayanan bimbingan dan konseling (Solihatun \& Folastri, 2019). Hal tersebut dilakukan agar konsentrasi dan motivasi siswa dalam belajar akan meningkat dan prestasi akademik pun akan baik (Fitriyanti, 2015). Adapun pemberian layanan dalam rangka membantu mengatasi kesulitan belajar Siswa yaitu melalui format kelompok dengan format kelompok tersebut diharapkanupaya pembentukan karakter Siswa juga dapat berkembang dengan positif, hal tersebut sejalan dengan pendapat (Rangkuti, 2014) menunjukkan bahwa rasa tanggung jawab dalam kegiatan akademik akan meningkat dengan melihat kendala-kendala atau kesulitan belajar yang dialami selama proses pembelajaran agar meningkatnya konsentrasi siswa itu sendiri. Peningkatan yang terjadi selama proses penelitian ini adalah pada siklus I terjadi peningkatan sebanyak 50\% lalu dilanjutkan ke siklus II dengan peningkatan sebanyak $75 \%$ dan pada siklus II ini peningkatan sudah mencapai target yang telahditentukan peneliti. Sehingga dapat disimpulkan bahwa rasa tanggung jawab Siswa dalam kegiatan akademik dapat meningkat dengan menggunakan teknik Pembelajaran Karakter Cerdas Format Kelompok.

Membentuk karakter dalam perspektif pembelajaran tidak bisa dilepaskan dari pilihan strategi di dalam kelas. Semakin tepat strategi yang dipilih akansemakin memperkuat dan mempercepat transformasi nilai-nilai ke dalam diri individuindividu dan akhirnya masyarakat. Desain pembelajaran di dalam kelas tidak bisa dilepaskan dari unsur-unsur yang ada di dalamnya (guru dan Siswa) sertapendukung yang lain seperti lingkungan belajar, bahan ajar serta sumber belajar. Kecermatan di dalam memanfaatkan unsur-unsur tersebut akan mendorong pembelajaran akan lebih baik dan dipercaya mampu menciptakan kepribadian Siswa sehingga menjadi Siswa dengan karakter akademik yang tangguh (Amri, 2013), agar Siswa nantinya memiliki karakter yang siap dan mumpuni di dalam mengikuti pendidikan di tingkat berikutnya dan juga proses pembelajaran di dalamnya.

Pendidikan karakter secara terperinci memiliki lima tujuan. Pertama, mengembangkan potensi kalbu/nurani/afektif peserta didik sebagai manusia dan warga Negara yang memiliki karakter bangsa. Kedua, mengembangkan kebiasaan dan prilaku peserta didik yang terpuji dan sejalan dengan nilai-nilai universal dan tradisi budaya bangsa yang religious. Ketiga, menanamkan jiwa kepemimpinan dan tanggungjawab peserta didik sebagai penerus bangsa. Keempat, mengembangkan kemampuan peserta didik menjadi manusia yang mandiri, kreatif, dan berwawasan kebangsaan. Kelima, mengembangkan lingkungan kehidupan sekolah sebagai 
lingkungan belajar yang aman, jujur, penuh kreativitas dan persahabatan, dan dengan rasa kebangsaan yang tinggidan penuh kekuatan (Omeri, 2015).

PKC-KO adalah kegiatan kelompok yang memanfaatkan dinamika kelompok dalam membahas suatu masalah ataupun topik yang memiliki nilai-nilai karakter. Prayitno (2014) mengungkapkan bahwa PKC-KO merupakan kegiatan kelompok yang mengahayati dan mengamalkan nilai-nilai karakter cerdas dalam wujud perilaku dan kehibupan pada umumnya. Pendidikan karakter cerdas format kelompok memiliki komponen yang hampir sama dengan komponen penyelenggaraan Bimbingan kelompok atau konseling kelompok yaitu nilai-nilai karakter cerdas inilah yang hal pokok yang membedakan antara PKC-KO dan bimbingan kelompok/konseling kelompok. Layanan bimbingan kelompok dan konseling kelompok merupakan suatu perkembangan profesional yang menjanjikan peningkatan kuantitas dan kualitas komunikasi pribadi. Anggota kelompok dapat berinteraksi dan berkomunikasi satu sama lain dengan konselor (pemimpin kelompok) tentang apa saja yang menjadi minat dan kebutuhan mereka (Folastri \& Rangka, 2016). Apabila dalam layanan bimbingan kelompok yang dibahas adalah masalah umum, dan PKC-KO topik-topik yang dibahas dengan acuankhusus, yaitu nilai-nilai karakter cerdas sebagaimana butir-butirnya dikemas dalamdalam buku saku.

Tujuan dalam pelaksanaan PKC-KO adalam memberikan pembelajaran dengan memasukkan nilai-nilai karakter cerdas sehingga benar-benar dihayati dan diamalkan dalam kehidupan sehari-hari. Meningkatnya suasana dan makna positif kehidupan pribadi dan social pada umumnya dengan acuan nilai-nilai karakter cerdas. Selain itu kegiatan PKC-KO diharapkan dapat memberikan dampak positif terkait dengan berbagai hal yaitu dihayatinya nilai-nilai karakter cerdas dalam konteks kehidupan nyata oleh subjek yang mengikuti kegiatan PKC-KO

Dalam pembinaan karakter cerdas ini, para Siswa diarahkan oleh guru BK agar dapat melaksanakan dan mengembangkan enam pilar karakter yang juga dikembangkan oleh the six pillar of character education Josephon Institut dikenal dengan Character Counts yang dikutip Samani \& Hariyanto (2011) yang terdiri dari:

a. Trustworthiness (keterpercayaan) Pilar pertama ini mengandung unsur-unsur berikut: (1) kejujuran, (2) tidak berbohong; (3) dapat dipercaya; 4) melakukan sesuatu sesuai dengan apa yang dikatakan; (4) keberanian bertindak atasdasar kebenaran; (5) pembangunan reputasi yang baik; dan (6) kesetiaan, baik pada keluarga, teman, dan negara.

b. Respect (rasa hormat) Komponen pembangun karakter ini adalah 1) memperlakukan orang lain dengan hormat; 2) menerima danbertoleransi dalam berbagai perbedaan; 3) berperilaku baik dan menghindari kata- kata kasar; 4) mempertimbangkan perasaan orang lain; 5) tidak mengancam, memukul atau mencederai orang lain; dan 6) menahan amarah, tidak menghina orang lain, dan tidak memaksakan ketidaksetujuan pada orang lain.

c. Responsibility (tanggungjawab). Bertanggungjawab dipahami dalam beberapa perspektif seperti melaksanakan kewajiban, membuat perencanaan, ketangguhan, berusaha melakukan yang terbaik, pengendalian diri, disiplin, berpikir sebelum bertindak, bertanggungjawab atas ucapan, perbuatan, dan sikap, dan menjadi teladan bagi orang lain.

d. Fairness (keadilan), yaitu kesediaan untuk bertindak adil bagi diri sendiri dan 
orang lain. Tindakan adil ini diindikasikan oleh kesediaan untuk mengikuti aturan main, memberikan kesempatan pada diri sendiri dan orang lain, berpikiran 3 terbuka (mau mendengar orang lain), tidak memanfaatkan orang lain, tidak menyalahkan orang lain dengan semena-mena, danmemperlakukan orang lain secara adil.

e. Caring (kepedulian) Secara nyata keperdulian ditandai oleh keramahan/kebaikan hati, simpati dan empati, rasa terima kasih, kemauan memaafkan orang lain, dan membantu orang yang tengah membutuhkan.

f. Citizenship (kewargaan) Nilai-nilai rasa persatuan ini dimanifestasikan dalam bentuk kontribusi nyata untuk membuat komunitas tempatia berada menjadi lebih baik, bekerjasama dengan orang lain, terlibat dalam kegiatan-kegiatan kemasyarakatan, terus mengikuti perkembangan informasi, menjadi anggota masyarakat yang baik, mematuhi hukum dan perundang-undangan, menghargai para pemimpin, perduli pada lingkungan, dan kesukarelaan.

Begitu banyaknya unsur-unsur yang terkandung dalam setiap pilar karakter diatas. Maka pada kesempatan ini tim ABDIMAS lebih terfokus pada salah satu pilar saja. Di sini penulis memilih untuk fokus pada pilar yang ketiga yaitu responsibility (tanggung jawab) terkait dengan akademik siswa (masalah kesulitan belajar).Siswa adalah agen perubahan di dunia ini sehingga penanaman rasa tanggung jawabsangatpenting untuk mereka. Siswa merupakan generasi penerus bangsa yang kelakakan memimpin Negara ini nantinya. Dengan adanya rasa tanggung jawab yang kuat dalam diri Siswa maka dapat menjadikan mereka sebagai pemimpin yang mampu melaksanakan tugas dan kewajibannya dalam hal akademik yaitu terkait masalah kesulitan belajar. Berdasarkan kondisi tersebut maka tim ABDIMAS berkesempatan untuk dapat melakukan kegiatan pengabdian masyarakat dengan tema PKC-KO untuk membantu mengatasi kesulitan belajar di SMK Tecma Ciambar.

Kegiatan ini bertujuan untuk memberikan pembinaan melalui penanaman dan pengembangan karakter cerdas dalam upaya meningkatkan karakter akademik siswa melalui format kelompok. Diharapkan melalui kegiatan ABDIMAS yang diberikan kepada Guru BK dan siswa dapat menambah WPKNS (Wawasan, Pengetahuan, Keterampilan, Nilai dan Sikap) dan juga memberikan solusi kepada para siswa untuk dapat mampu mengatasi permasalahan, hambatan, dan juga kesulitan di dalam belajar pada proses pembelajaran, sehinggaSiswa dapat secara optimal melaksanakan tugas perkembangannya di dalam bidangakademis terutama dalam pencapaian hasil belajar. Guru BK dapat meningkatkan kemampuan pemberian layanan konseling melalui $\mathrm{PKC}-\mathrm{KO}$ yang dilatihkannya bersama dengan tim melalui kegiatan pengabdian kepada masyarakat.

\section{METODE PELAKSANAAN}

Kegiatan pengabdian kepada masyarakat ini dilaksanakan selama 3 hari pada tanggal 5-7 Juni 2021, dikarenakan kondisi pandemi COVID-19 yang masih terjadi dan untuk mencegah terjadinya penyebaran virus tersebut maka kami tim pelaksana kegiatan pengabdian kepada masyarakat melaksanakan kegiatan tersebut dengan jarak jauh melalui aplikasi zoom. Metode pelaksanaan pengabdian kepada masyarakat dilakukan dengan cara membuat suatu pembinaan melalui pelatihan dan sosialisasi terhadap mitra/peserta yang berjumlah 2 orang guru BK dan 25 Siswa. 
Kegiatan dimulai dengan melakukan survei awal ke lokasi mitra untuk mengetahui apa saja kendala dan permasalahan yang sedang dihadapi oleh mitra melalui wawancara dan observasi.

Setelah mengetahui pokok-pokok permasalahan yang sedang dihadapi oleh mitra yaitu banyaknya siswa yang mengalami kesulitan blajar terutama di saat pandemi COVID-19 dan terbatasnya pelayanan konseling yang di berikan oleh guru BK, maka selanjutnya Tim pelaksana pengabdian kepada masyarakat mendalami permasalahan tersebut untuk kemudian mencari solusinya melalui strategiPKC-KO untuk membantu mengatasi kesulitan belajar. Kegiatan pelatihan dilakukan dengan memberikan materi-materi yang telah disiapkan oleh Tim pelaksana pengabdian kepada masyarakat. Adapun materi yang disampaikan diantaranya ialah tentang pokok- pokok PKC-KO, pelatihan PKC-KO kepada guru BK dan mempraktikannya secara langsung kepada siswa, dimana pada saat proses pelatihan pemateri menyelinginya dengan beberapa demonstrasi dandiskusi tanya jawab.

\section{HASIL DAN PEMBAHASAN}

Hasil kegiatan pengabdian kepada masyarakat yang dilakukan oleh tim dalam pelaksanaannya yaitu, Pembinaan PKC-KO untuk membantu mengatasi kesulitan belajar di SMK Tecma Ciambar. Adapun kegiatan-kegiatan yang telah dilakukan adalah sebagai berikut.

\section{Hari 1}

a. Sosialisasi akan diadakannya kegiatan ABDIMAS kepada mitra terlebihkhusus kepada guru BK yang bertugas di SMK Tecma Ciambar.

b. Peninjauan lokasi tempat kegiatan pengabdian kepada masyarakat melalui aplikasi Video Calla Whatsapp

c. Identifikasi permasalahan yang sedang dirasakan oleh mitra melalui wawancara dan observasi.

d. Identifikasi alat-alat yang dibutuhkan pada saat kegiatan pengabdiankepada masyarakat untuk mitra dilaksanakan.

e. Identifikasi materi yang akan diberikan kepada mitra.

f. Mempersiapkan kegiatan ABDIMAS kepada mitra dengan tema PKM Pembinaan PKC-KO untuk membantu mengatasi kesulitan belajar di SMK Tecma Ciambar.

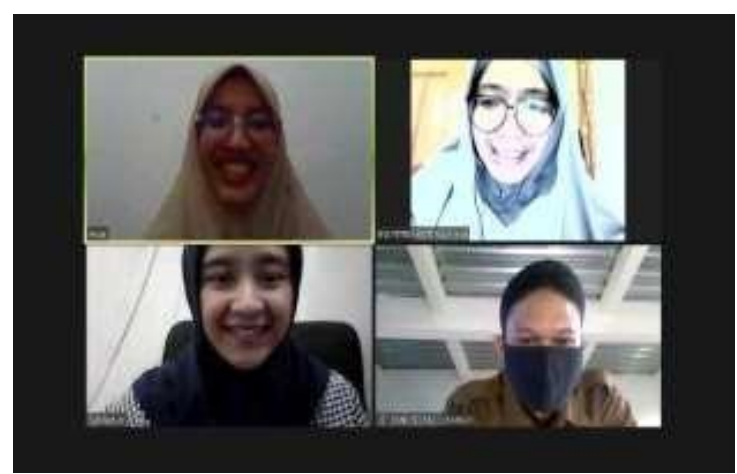

Gambar 1. Koordinasi persiapan kegiatan pengabdian kepada masyarakat 


\section{Hari 2}

a. Persiapan Pemaparan materi kepada mitra mengenai PkM Pembinaan PKC-KO untuk membantu mengatasi kesulitan belajar di SMK Tecma Ciambar.

b. Memberikan link zoom kepada para peserta kegiatan

c. Menunggu keseluruhan para peserta dapat masuk ke zoom

d. Pengisian presensi kehadiran

e. Perkenalan tim ABDIMAS dan menjelaska maksud serta tujuan di adakannya kegiatan ABDIMAS secara menyeluruh kepada peserta

f. Pelaksanaan kegiatan pengabdian kepada masyarakat, yaitu pemberian materi mengenai Pembinaan PKC-KO untuk membantu mengatasi kesulitan belajar kepada mitra.

g. Menyimak bersama materi yang di sampaikan oleh anggota tim ABDIMAS kepada para peserta.

h. Diskusi dan tanya jawab terkait Pembinaan PKC-KO untuk membantu mengatasi kesulitan belajar yang sudah diberikan.

i. Kesan dan pesan dari mitra setelah mendapatkan materi Pembinaan PKC-KO untuk membantu mengatasi kesulitan belajar.

j. Layseg oleh Tim ABDIMAS.

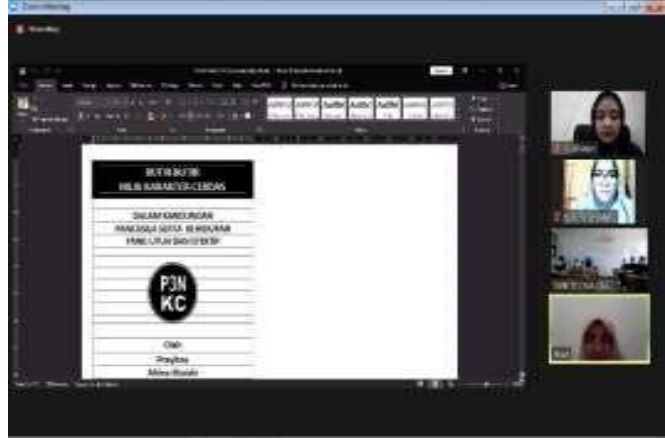

Gambar 2. Pemberian Materi PKC-KO kepada Peserta

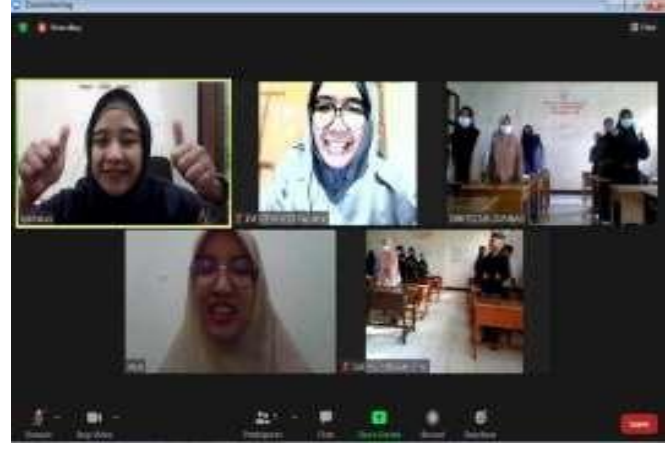

Gambar 3. Pemberian Penguatan kepada Peserta

\section{Hari Ke 3}

a. Penerapan Pembinaan PKC-KO Untuk Membantu Mengatasi Kesulitan Belajar melalui kelompok-kelompok oleh guru BK di sekolah

b. Kesan dan pesan dari mitra setelah melaksanakan dan menerapkan secara langsung kegiatan Pembinaan PKC-KO Untuk Membantu Mengatasi KesulitanBelajar.

c. Layseg oleh tim ABDIMAS

d. Penutupan kegiatan

Banyak cara yang dilakukan untuk mengatasi krisis karakter yang terjadi saat ini terutama pada dunia pendidikan. Dengan adanya PKC-KO maka sangat membantu di dalam mengatasi permasalahan karakter cerdas yang keberadaannya semakin jauh dari diri peserta didik. Pelaksanaan PKC-KO dapat dilaksanakan oleh siapa saja yang telah mendapatkan pelatihan khusus, PKC-KO dapat diberikan diberbagai lapisan masyarakat, baik dalam dunia pendidikan formal, non formal maupun dikalangan masyarakat umum seperti pegawai pemerintah maupum non pemerintah. PKC-KO merupakan kegiatan yang memberikan pembelajarm bagi 
anggota kelompok maupun fasilitator. Dengan adanya pelaksanaan PKC-KO baik anggota kelompok maupun fasilitator dapat mengarahkan kepada pengamalan dan penghayatan nilai- nilai karakler cerdas yang terdapat pada buku saku. Apabila kegiatan terscbutdiikutioleh anggota dengan baik, maka dalam kehidupan efektif mereka sehari-hari akan tercerminkan nilai-nilai karakter yang positif (Putri \& Ramadhani, 2018).

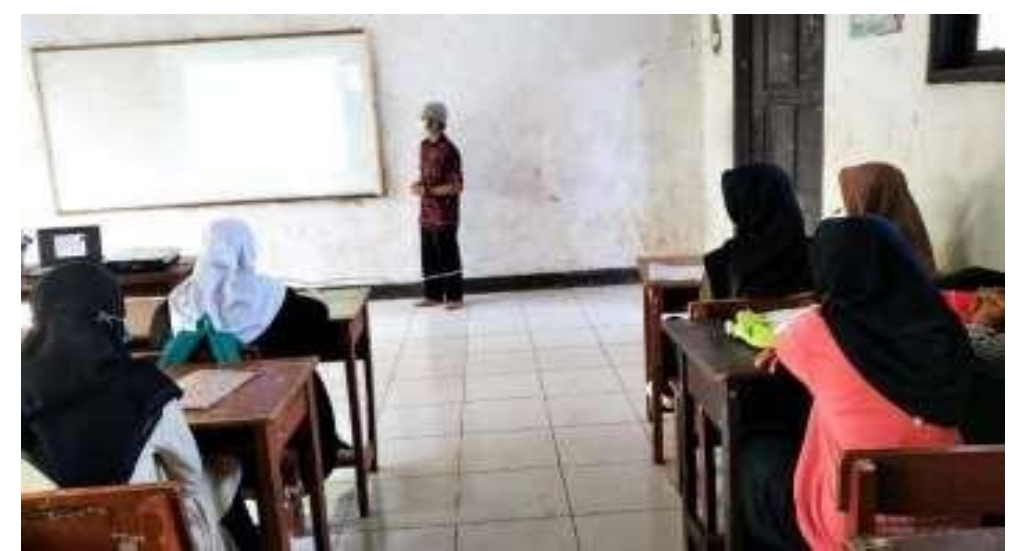

Gambar 4. Praktik PKC-KO untuk Membantu Mengatasi

Kesulitan Belajar oleh Guru BK kepada Siswa

Sesuai dengan kondisi tersebut, berdasarkan kegiatan pengabdian kepada masyarakat yang telah dilakukan oleh tim pelaksana maka dapat di kaji bahwa dengan diterapkannya kegiatan pembinaan PKC-KO untuk membantu mengatasi kesulitan belajar di SMK Tecma Ciambar dapat memberikan wawasan, pengetahuan, keterampilan, nilai, dan sikap kepada para pendidik terlebih khusus Guru BK untuk dapat melaksanakan secara mandiri kegiatan pelayanan konseling melaluiPembinaan PKC-KO untuk membantu mengatasi kesulitan belajar yang dapat diberikan kepada para siswa di sekolah. Kemudian dengan pemberdayaan sumber daya manusia di dalam kegiatan pengabdian masyarakat ini yaitu Guru BK di SMK Tecma Ciambar, maka kegiatan pengabdian masyarakat yang telah dilaksanakan memiliki kebermanfaatan dalam memperkaya dan meningkatkan keterampilan guru BK dalam melaksanakan pelayanan konseling terutama melalui kegiatankonseling dengan format kelompok PKC-KO untuk mengatasi kesulitan belajar yang dihadapi oleh para siswa.

\section{SIMPULAN}

Berdasarkan hasil kegiatan pengabdian kepada masyarakat yang dilakukan dapat disimpulkan bahwa kegiatan ini memiliki kebermanfaatan dalam pelaksanaan pembinaan PKC-KO untuk membantu mengatasi kesulitan belajar di SMK Tecma Ciambar, dimana melalui pelaksanaannya dapat membantu meningkatkan wawasan, pengetahuan, keterampilan, nilai, dan sikap Guru BK sebagai konselor di sekolah untuk dapat mengoptimalkan tugas tugas dan tanggungjawabnya dalam melaksanakan layanan BK berdasarkan teknik-teknik konseling kepada klien. Keberhasilan ini dapat ditunjukkan dengan adanya respon positif yang ditunjukkan dengan keaktifan dari peserta kegiatan dalam mengajukan suatu pertanyaan atau menanggapi materi yang disampaikan berkenaan dengan materi pembinaan PKC- 
KO untuk membantu mengatasi kesulitan belajar, adanya perubahan kearah yang positif dengan terlihatnya penambahan wawasan, pengetahuan, keterampilan, nilai, dan sikap dalam mengolah materi yang diberikan oleh tim pengabdian kepada masyarakat terutama dalam pelaksanaan PKC-KO untuk membantu mengatasi kesulitan belajar, adanya keterbukaan mengenai permasalahan yang disampaikan oleh para mitra yaitu guru BK di SMK Tecma Ciambar berkaitan dengan tugas sebagaikonselor di sekolah dalam mengoptimalkan kehidupan efektif sehari-hari para siswa di sekolah tersebut sehingga mengoptimalkan penanaman nlai-nilai karakter cerdas di dalam diri para siswa dan tercerminkan di dalam kehidupan sehari-hari.

\section{UCAPAN TERIMA KASIH}

Terimakasih kepada LPPM Universitas Indraprasta PGRI yang telah menaungi kegiatan penelitian dan pengabdian kepada masyarakat yang dilakukan oleh para dosen. Kepada SMK Tecma Ciambar sebagai mitra dalam kegiatanpengabdian kepada masyarakat dan juga kepada pada Jurnal Abdimas Prakasa Dakara atas kesempatan publikasi kami sampaikan terimakasih.

\section{DAFTAR PUSTAKA}

Amri, M. (2013). Urgensi Pembelajaran Bagi Pengembangan Karakter Akademik Mahasiswa Pendidikan Tinggi. Lentera Pendidikan: Jurnal Ilmu Tarbiyah Dan Keguruan, 16(2), 139-150. https://doi.org/10.24252/lp.2013v16n2a2.

Fitriyanti, E. (2015). Pengaruh Motivasi Belajar Dan Persepsi Siswa Atas Layanan KonselingTerhadap Prestasi Belajar Pada Mata Pelajaran IPS. Sosio E-Kons, 7(2), 90- 99. http://dx.doi.org/10.30998/sosioekons.v7i2.484

Ilyas, A., Folastri, S., \& Solihatun, S. (2017). Diagnosa Kesulitan Belajar \& Pembelajaran Remidial. Jakarta: Perpustakaan Nasional: Katalog Dalam Terbitan (KTD).

Omeri, N. (2015). Pentingnya pendidikan karakter dalam dunia pendidikan. Manajer Pendidikan, 9(3), 464-468.

Prayitno. (2014). Jenis Layanan dan Kegiatan Penduhng Konseling. Padang: FIP UNP.

Putri, R. D., \& Ramadhani, E. (2018). Pendidikan Karakter Cerdas Format Kelompok (PKC-KO) dalam Membentuk Karakter Penerus Bangsa. Jurnal Dosen Universitas PGRI Palembang. https://jurnal.univpgri palembang.ac.id/index.php/prosiding/article/view/1490/1300

Rangkuti, N. (2014). Meningkatkan Rasa Tanggung Jawab dalam Kegiatan Akademik melalui Pembelajaran Karakter Cerdas Format Kelompok Pkc Ko pada Konselor Sebaya di Universitas Negeri Medan Tahun 2014. UNIMED. http://digilib.unimed.ac.id/7809/5/1102151012\%20BAB\%20I.pdf.

Samani, M., \& Hariyanto, M. S. (2011). Konsep dan Model Pendidikan Karakter. Bandung: PT Remaja Rosdakarya.

Solihatun, S. (2019). Gambaran Kesulitan Belajar Siswa Serta Implikasinya Terhadap PelayananBimbingan dan Konseling. Jurnal Counseling Care, 2(2), 56-64. https://doi.org/10.22202/jcc.2018.v2i2.3061

Solihatun, S., \& Folastri, S. (2019). Program bimbingan dan konseling untuk 
mengatasi kesulitan belajar siswa SD Negeri 05 Ciganjur Jakarta Selatan. Teraputik: Jurnal Bimbingan Dan Konseling, 3(1), 35-40. https://doi.org/10.30998/teraputik.31122

Winarti, P. (2021). Analisis Kesulitan Belajar Mahasiswa dalam Perkuliahan Konsep Dasar IPA Fisika Secara Daring di Masa Pandemi COVID-19. Jurnal Komunikasi Pendidikan, 5(1), 93-107. https://doi.org/10.32585/jkp.v5i1.1076

Zulfahmi, Z., \& Handayani, F. (2020). Analisis Kesulitan Belajar Mahasiswa DalamPerkuliahan dan Praktikum Kimia Dasar Jurusan Farmasi Universitas Ubudiah Indonesia.. Journal of Education Science, 6(1), 86-95. https://doi.org/10.3314/jes.v6i1.831 